\title{
KAJIAN TEKNO EKONOMI PENDIRIAN INDUSTRI KARET BANTALAN JEMBATAN JENIS KARET ALAM DAN KARET KLOROPRENA
}

\author{
Techno Economic Studies on Industrial Establishment of ElastomericBridge Bearing \\ from Natural andChloroprene Rubbers \\ Santi Puspitasari , Adi Cifriadi dan Asron Ferdian Falaah \\ Pusat Penelitian Karet, Jalan Salak Nomor 1, Bogor, 16151 Jawa Barat \\ Email: puspitasari.santi@puslitkaret.co.id
}

Diterima 9 Januari 2017 / Direvisi 19 Mei 2017 / Disetujui 24 Mei 2017

\begin{abstract}
Abstrak
Peningkatan konsumsi domestik karet alam melalui pemanfaatan produk karet untuk mendukung pembangunan infrastruktur menjadi solusi memperkuat harga karet alam yang sejak akhir 2011 terus mengalami pelemahan. Produk karet bantalan jembatan yang berfungsi sebagai isolator pelindung struktur jembatan dari getaran dan beban lalu lintas berpotensi dikembangkan karena permintaan yang tinggi di pasaran. Dalam artikel ini diulas kajian tekno-ekonomi pendirian industri karet bantalan jembatan dari karet alam dan kloroprena dari aspek teknik hingga ekonomi.Data primer diperoleh secara survei melalui teknik wawancara kepada responden yang dipilih secara sengaja, sedangkan data sekunder diperoleh dengan menerapkan teknik multiplikasi dokumen dan pencatatan data dari instansi terkait. Analisa data menggunakan metode deskriptif kualitatif dan kuantitatif. Dari hasil kajian diketahui bahwapotensi pasar produk karet bantalan jembatan masih terbuka sebesar 57.000 buah pada tahun 2016. Kapasitas produksi ditetapkan sebesar 17.000 buah per tahun (30\%) dengan komposisi 75\% karet bantalan terbuat dari karet alam dan $25 \%$ dari karet kloroprena. Ukuran karet bantalan yang diproduksi mengacu pada ukuran standar yang ditetapkan oleh kementerian PUPR, yaitu tipe $1: 350 \times 300 \times 36 \mathrm{~mm}(30 \%)$, tipe 2 : $400 \times 350 \times 39 \mathrm{~mm}(35 \%)$, dan tipe 3 : 450x400x45 mm (35\%). Hasil kelayakan finansial menunjukkan bahwa industri karet
\end{abstract}

bantalan jembatan dan jalan layang layak didirikan karena memberikan nilai NPV sebesar IDR 14,22 Milyar (bernilai positif), IRR sebesar 20,10\% (lebih besar dari faktor diskonto $14 \%$ ), B/C rasio sebesar 1,22 (lebih besar dari 1) dan PBP selama 4,78 tahun. Industri ini sangat sensitif terhadap penurunan harga jual produk dan kenaikan nilai tukar USD terhadap IDR.

Kata kunci: konsumsi domestik karet alam, industri hilir karet, bantalan jembatan

\section{Abstract}

Increasing on natural rubber domestic consumption by the implementation of rubber goods to support the nfrastructure development had been regarded as best solution to strengthen natural rubber price which since the end of 2011 continues to weaken. Elastomeric bridge bearing that serves as isolator element to protect bridge from vibration and traffic load is potential to be developed due to the high market demand. The articles studied techno economic aspects of development new rubber bearing industry based on natural and chloroprene rubbers. The primary data was collected by survey method through interview to purposive respondences, while the secondary data was obtained by document multiplication technique and colleting informations from related institutions. The data analyzed using qualitative and quantitative descriptive method. The result showed that market potential of elastomeric bridge bearing product as 57,000 pcs in 2016. The production capacity was determined as 30\% of market potential (17,000 pcs per year), with 
composition as $75 \%$ of natural rubber and $25 \%$ of chloroprene rubber. Produced of the dimension of elastomeric bearing pads refers to General Work and Public Housing Ministry Regulation such type 1: $350 \times 300 \times 36 \mathrm{~mm}$ (30\%), type 2: $400 \times 350 \times 39$ $\mathrm{mm}$ (35\%), and type 3: $450 \times 400 \times 45 \mathrm{~mm}$ (35\%). The financial feasibility indicator aspositive NPV value (IDR 14,22 billion), IRR as 20.10\% (IRR > Discount Factor $14 \%), B / C$ ratio as 1.22 and $P B P$ as 4.78 year, the elastomeric bridge bearing industry was feasible to be developed. The industry very sensitive to dectrease of selling price and currency exchange rate of USD to IDR.

Keywords: natural rubber domestic consumption, downstream rubber industry, bridge bearing

\section{Pendahuluan}

Harga karet alam terus mengalami penurunan terhitung sejak akhir tahun 2011 hingga saat ini. Pada awal hingga pertengahan tahun 2011, harga karet alam mencapai lebih dari USD 5,5 per kg karet kering, namun di pertengahan tahun 2016 harga karet alam belum mampu bergerak dari kisaran USD 1,2 per $\mathrm{kg}$ karet kering. Penurunan harga karet alam memberikan dampak negatif bagi agroindustri karet nasional terutama industri karet di sektor hulu yang mencakup perkebunan karet, baik milik petani maupun perkebunan besar negara dan swasta, serta industri pengolahan karet mentah (karet remah dan karet sit asap). Kondisi penurunan harga karet alam sangat dipengaruhi oleh situasi permintaan dan penawaran karet alam. Melemahnya permintaan karet alam dari negara konsumen yang diikuti dengan peningkatan produksi di negara produsen mengakibatkan terdapatnya pasokan karet alam yang melimpah yang diikuti oleh penurunan harga jual karet alam.

Pemerintah selaku pengambil kebijakan wajib memberikan solusi atas kondisi pasar karet alam yang sedang menurundengan maksud untuk memperbaiki harga karet alam dan dapat melindungi para pelaku di sektor industri hulu karet khususnya petani. Pemerintah Indonesia yang turut tergabung dalam organisasi International Tripartite Rubber Council (ITRC) berkomitmen dengan anggota yang lain untuk meningkatkan keseimbangan permintaan dan penawaran karet alam dengan menerapkan tiga skema kesepakatan yaitu 1) supply management scheme (SMS), 2) agree export tonnage scheme (AETS), and 3) strategic market operation (SMO). Salah satu langkah penerapan strategi tersebut adalah dengan menambah konsumsi domestik karet alam di setiap negara produsen utama karet alam.

Indonesia hanya menyerap sekitar 550 ribu ton atau $18 \%$ dari total produksi karet alam nasional pada tahun 2015 untuk memenuhi kebutuhan industri hilir karet lokal. Industri ban merupakan konsumen utama karet alam. Produk konvensional karet alam seperti ban, sol alas kaki, sarung tangan lateks, dan selang karet belum sepenuhnya mampu meningkatkan konsumsi domestik karet alam. Kemajuan penelitian dan pengembangan karet alam menunjukkan bahwa sektor infrastruktur dan konstruksi dianggap mampu menyerap karet alam dalam jumlah besar sehingga dapat meningkatkan konsumsinya. Produk karet alam yang dapat diaplikasikan dalam bidang tersebut antara lain a) karet sebagai bahan aditif untuk pembuatan aspal karet (rubberizedasphalt), b) karet untuk bantalan dermaga (dock fender), c) karet bantalan untuk bangunan tahan gempa (seismic bearing), d) karet untuk bantalan rel kereta api (rail pad), dan d) karet bantalan untuk perletakan jembatan dan jalan layang (elastomeric bearing pad).

Sebagian besar industri manufaktur barang jadi karet untuk aplikasi dalam bidang infrastruktur dan konstruksi merupakan industri skala UKM. Untuk memperkuat kinerja industri hilir karet tersebut, Pemerintah menerbitkan kebijakan tentang rekomendasi penggunaan produk karet untuk memenuhi kebutuhan proyek pembangunan infrastruktur dan konstruksi yang didanai oleh APBN. Kebijakan ini akan dituangkan dalam Instruksi Presiden. Dengan diberlakukannya Instruksi Presiden tersebut 
diharapkan industri hilir karet nasional dapat semakin berkembang, bahkan dapat memunculkan industri baru yang serupa. Dengan demikian target Pemerintah untuk menambah konsumsi karet domestik serta memperbaiki harga karet dapat segera terealisasi dengan baik.

Industri karet bantalan untuk perletakan jembatan dan jalan layang menjadi salah satu industri karet yang patut untuk segera dikembangkan mengingat banyaknya proyek pembangunan infrastruktur jalan layang dan jembatan yang menjadi prioritas pemerintah dalam rencana pembangunan nasional periode 2016 - 2019. Selama ini kebutuhan perusahaan konstruksi selaku pelaksana proyek pembangunan infrastruktur jalan dan jembatan terhadap karet bantalan untuk perletakan jembatan dan jalan layang sebagian besar masih dipenuhi secara impor terutama dari China dan Malaysia. Artikel ini mengulas potensi pasar serta kajian tekno ekonomi pendirian industri manufaktur karet bantalan untuk perletakan jembatan dan jalan layang.

\section{Bahan dan Metode}

Kajian pembangunan industri karet bantalan untuk perletakan jembatan dan jalan layang dilakukan dengan menerapkan beberapa metode untuk mendapatkan datadata pendukung baik primer maupun sekunder. Data primer diperoleh dengan metode survei melalui teknik wawancara kepada para responden yang dipilih secara sengaja (purposive). Responden yang ditetapkan dalam kajian ini melibatkan antara lain pihak manajemen pengelola kawasan industri, produsen karet bantalan jembatan dan jalan layang eksisting, serta produsen, importir atau supplier bahan kimia karet. Sedangkan pencarian data sekunder dilakukan dengan menerapkan teknik multiplikasi dokumen dan pencatatan data dari instansi terkait lainnya.

Data yang diperoleh selanjutnya diolah menggunakan analisis deskriptif kualitatif dan kuantitatif. Analisis kualitatif dilakukan dengan mengkaji potensi pasar, rencana lokasi pendirian pabrik, serta teknologi produksi. Sementara analisis kuantitatif dilakukan melalui pendekatan kelayakan finansial dengan empat kriteria investasi proyek yaitu Net Present Value (NPV), Internal Rate of Return (IRR), Benefit Cost Ratio (B/C Ratio), dan Payback Period (PBP). Analisis sensitivitas turut diperhitungkan dalam analisis kuantitatif dengan menerapkan berbagai variabel yang mempengaruhi kelayakan finansialnya.

\section{Hasil dan Pembahasan}

\section{Karet Bantalan untuk Perletakan Jembatan dan Jalan Layang}

Jembatan dan jalan layang dirancang memiliki umur pakai yang lama serta tahan terhadap gangguan alam seperti gempa bumi mengingat perannya yang cukup vital dalam menunjang kelancaran aktivitas transportasi (Alam et al., 2012). Dengan memasang suatu sistem isolasi seperti karet bantalan (bearing pad) yang dapat menyerap gangguan tersebut, diharapkan dapat memperpanjang umur pakai serta memperkuat struktur jembatan dan jalan layangsehingga meningkatkan ketahanannya terhadap getaran yang timbul akibat gempa bumi (Manos et al., 2007; Kitaharaet al., 2012; Weisman and Warn, 2012; Filipov et al., 2012; Asl et al., 2014; Warn and Ryan, 2012). Teknologi ini dinilai cukup efektif dan berbiaya relatif rendah (Haque et al., 2013).Elemen ini bekerja dengan meneruskan beban dari bangunan atas ke bangunan bawah yang dipasang diantara badan/gelagar (super structure) dan pilar/tiang (sub structure) (Iancuet al., 2012).

Berbagai tipe karet bantalan untuk perletakan jembatan dan jalan layang telah diaplikasikan, mulai dari tipe polos yang hanya terdiri dari satu lapisan karet tanpa lempeng baja, dan tipe berlapis yang terdiri atas 2 atau lebih lapisan karet alam maupun sintetik dan lempeng baja (Ravari et al., 2011). Karet bantalan tipe berlapis (laminated rubber bearing) telah luas digunakan terutama 
untuk jembatan di wilayah rawan gempa seperti Jepang, sehingga sangat cocok untuk juga dapat diterapkan di Indonesia (Aviram et al., 2012). Karet bantalan memiliki kemampuan untuk menciptakan kekakuan vertikal sekaligus fleksibilitas horizontal, tidak terkorosi, mudah saat penggantian dan hanya membutuhkan teknik pemeliharaan yang sederhana, serta biaya instalasi yang rendah (Razzaq et al., 2010; Bhuiyan and Alam, 2012; Steelman et al., 2013, Haqueet al., 2010; Sanchez et al., 2013; Liu et al., 2008; Ravari et al., 2012; Alam and Bhuiyan, 2012). Dengan kekakuan yang tinggi maka ketinggian permukaan jembatan atau jalan layang relatif stabil pada saat dikenai beban vertikal dari berat kendaraan dan gelagar jembatan.Sedangkan fleksibilitas horizontal berguna untuk melindung konstruksi akibat terkena ekspansi panas atau beban kejut yang timbul pada saat kendaraan memasuki landasan jembatan, serta getaran akibat terjadinya gempa bumi (Yachya, 1988; Choun et al., 2014).

Karet bantalan untuk perletakan jembatan dan jalan layang akan selalu terpapar oleh udara dan sinar matahari sehingga sangat rentan terhadap proses oksidasi termal yang dapat mengubah sifat-sifatnya (Itoh \& Gu, 2009; Ohkura et al., 2011). Kerusakan karet karena oksidasi termal menyebabkan karet menjadi keras namun rapuh, sehingga karet bantalan tidak mampu menahan deformasi dan menyerap energi yang pada akhirnya akan merusak sistem keamanan jembatan atau jalan layang tersebut (Ohkura et al., 2011; Gu \& Itoh, 2012). Untuk meminimalkan kerusakan atau degradasi karet akibat proses oksidasi, maka dalam manufaktur karet bantalan untuk perletakan jembatan dan jalan layang harus menggunakan karet yang tahan terhadap oksidasi seperti karet sintetik tipe Kloroprena (CR). Dengan formulasi kompon karet yang tepat maka karet alam dapat digunakan sebagai base elastomer dalam pembuatan karet bantalan untuk perletakan jembatan dan jalan layang. Ketahanan oksidasi karet alam dapat ditingkatkan dengan penambahan bahan antioksidasi dan antiozonan yang tepat dalam formula kompon karetnya.Mutu karet bantalan untuk perletakan jembatan dan jalan yang telah digunakan di Indonesia diatur dalam SNI 3966:2012 dan SNI 3967:2013.

\section{Kajian Tekno Ekonomi}

Kajian tekno ekonomi dimaksudkan untuk mengetahui kelayakan pembangunan industri karet bantalan untuk perletakan jembatan dan jalan layang. Kajian tekno ekonomi mencakup beberapa aspek yaitu potensi pasar yang masih terbuka, pemilihan rencana lokasi pendirian pabrik, penentuan kapasitas produksi, penentuan teknologi proses produksi dan analisis finansial.

\section{Potensi Pasar}

Pemerintah mentargetkan peningkatan konsumsi domestik karet alam sebesar 500 ribu ton dalam periode 2015 - 2019.Beberapa kementerian terkait telah ditunjuk untuk melaksanakan target pemerintah tersebut, antara lain Kementerian PUPR sebesar 250 ribu ton, Kemenperin sebesar 100 ribu ton, Kemenhub sebesar 100 ribu ton, dan 50 ribu ton oleh Kementerian BUMN. Bagi Kementerian PUPR yang mendapatkan jatah penyerapan karet alam terbanyak akan dialokasikan untuk mendukung pembangunan infrastruktur nasional. Berdasarkan informasi dalam APBN 2016, Kementerian PUPR melaksanakan program pembangunan jembatan sepanjang $8.052 \mathrm{~m}$, pemeliharaan jembatan yang telah ada sepanjang $378.310 \mathrm{~m}$ dan pembangunan jalan layang sepanjang $29.664 \mathrm{~m}$.

Karet bantalan untuk perletakan jembatan dan jalan layang berpeluang digunakan untuk mendukung pembangunan infrastruktur jembatan dan jalan layang.Apabila diasumsikan bahwa setiap 30 meter panjang jembatan atau jalan layang memerlukan 24 buah karet bantalan, hanya $80 \%$ jembatan dan jalan layang yang akan dipasang karet bantalanserta $20 \%$ jembatan eksisting yang akan dipasang karet bantalan untuk pemeliharaan, maka untuk memenuhi 
kebutuhan proyek infrastruktur jembatan dan jalan layang di tahun 2016, pemerintah memerlukan pasokan karet bantalan untuk perletakan jembatan dan jalan layang sebanyak 84.668 buah, seperti diuraikan dalam Tabel 1 berikut.

Tabel 1.Permintaan karet bantalan untuk perletakan jembatan dan jalan layang 2016

$\begin{array}{cccc}\begin{array}{c}\text { Program infrastruktur } \\ \text { Pemerintah }\end{array} & \begin{array}{c}\text { Panjang total } \\ \text { (m) }\end{array} & \begin{array}{c}\text { Panjang dipasang } \\ \text { karet bantalan }\end{array} & \begin{array}{c}\text { Jumlah karet bantalan } \\ \text { (buah) }\end{array}\end{array}$

\begin{tabular}{lrrr}
\multicolumn{1}{c}{ Pemerintah } & $(\mathrm{m})$ & $\begin{array}{c}\text { karet bantalan } \\
(\mathrm{m})\end{array}$ & (buah) \\
\hline Pembangunan jembatan & 8.052 & 6.442 & 5.153 \\
Pemeliharaan jembatan & 378.310 & 75.662 & 60.530 \\
Pembangunan jalan layang & 29.664 & 23.731 & 18.985 \\
$\quad$ Total & 416.026 & 105.835 & 84.668 \\
\hline
\end{tabular}

Sumber (Source) : Kementerian Keuangan, 2015

Pada rentang 3 tahun antara 2012 - 2014, proporsi impor terhadap ekspor karet bantalan untuk perletakan jembatan dan jalan layang cukup tinggi rata-rata mencapai $82 \%$ atau sebesar 20.299 buah karet bantalan impor terhadap 3.715 buah karet bantalan ekspor seperti disajikan dalam Tabel 2 berikut. Tingginya kuantitas impor karet bantalan diperkirakan dikarenakan industri infrastruktur di dalam negeri lebih mempercayai kualitas produk karet bantalan impor. Meskipun sebenarnya industri karet bantalan lokal didukung oleh lembaga riset, telah mampu memproduksi karet bantalan yang berkualitas setara bahkan lebih baik dibandingkan dengan produk impor. Apabila industri karet bantalan lokal yang telah eksis mampu merebut pasar impor, maka akan membuka potensi pasar karet bantalan untuk perletakan jembatan dan jalan layang yang cukup luas.

Pasar lokal karet bantalan untuk perletakan jembatan dan jalan layang diasumsikan sebanding dengan kuantitas ekspor.Dengan demikian dapat diketahui bahwa produksi nasional karet bantalan untuk perletakan jembatan dan jalan layang setara dengan total penjumlahan antara pasar lokal dan kuantitas ekspornya sebesar 7.429 buah.

Tabel 2. Ekspor impor karet bantalan untuk perletakan jembatan dan jalan layang

\begin{tabular}{lcccccc}
\hline \multirow{2}{*}{ Bulan } & \multicolumn{6}{c}{ Tahun (buah) } \\
\cline { 2 - 7 } & \multicolumn{2}{c}{2012} & \multicolumn{2}{c}{2013} & \multicolumn{2}{c}{2014} \\
\cline { 2 - 7 } & Ekspor & Impor & Ekspor & Impor & Ekspor & Impor \\
\hline Januari & 186 & 736 & 227 & 2.429 & 110 & 1.438 \\
Februari & 582 & 1.001 & 170 & 1.939 & 211 & 617 \\
Maret & 951 & 2.170 & 264 & 1.270 & 306 & 1.217 \\
April & 690 & 1.264 & 301 & 2.690 & 311 & 3.968 \\
Mei & 258 & 1.037 & 43 & 2.836 & 1.267 & 693 \\
Juni & 784 & 2.414 & 270 & 1.785 & 216 & 1.128 \\
Juli & 349 & 1.775 & 437 & 1.227 & 241 & 646 \\
Agustus & 57 & 1.166 & 27 & 1.327 & 220 & 1.159 \\
September & 174 & 1.411 & 233 & 556 & 379 & 7.286 \\
Oktober & 377 & 1.008 & 150 & 1.362 & 333 & 5.504 \\
November & 447 & 1.668 & 133 & 1.069 & $N A$ & $N A$ \\
Desember & 203 & 1.776 & 237 & 1.326 & $N A$ & $N A$ \\
$\quad$ Jumlah & 5.058 & 17.427 & 2.493 & 19.815 & 3.593 & 23.656 \\
\hline
\end{tabular}

Sumber (Source) : Badan Pusat Statistik, 2015 
Dari data yang telah diuraikan terlihat jika jumlah produksi nasional masih jauh di bawah permintaan pasokan karet bantalan untuk pembangunan infrastruktur nasional di tahun 2016. Hal ini berarti masih tersedia potensi pasar yang dapat dimanfaatkan oleh industri karet bantalan untuk perletakan jembatan dan jalan layang eksisting maupun baru. Potensi pasar dapat diperhitungkan yaitu sebesar selisih antara permintaan terhadap total produksi nasional dan kuantitas impor. Hasil perhitungan diperoleh potensi pasar karet bantalan untuk perletakan jembatan dan jalan layang yang masih terbuka sebesar 56.939 buah (57.000 buah) pada tahun 2016 .

\section{Pemilihan Rencana Lokasi Pendirian Pabrik}

Penentuan rencana lokasi pendirian industri perlu dipertimbangkan secara matang karena memiliki dampak yang cukup signifikan terhadap keberlangsungan hidup industri tersebut. Lokasi pendirian industri harus mampu memberikan efektivitas dan efisiensi dalam proses produksi dari bahan baku menjadi produk hingga transportasi produk sampai ke pelanggan. Industri manufaktur karet bantalan untuk perletakan jembatan dan jalan layang direncanakan akan didirikan di Kawasan Industri Sentul, Kecamatan Babakan Madang, Kabupaten Bogor, Provinsi Jawa Barat (Gambar 1).

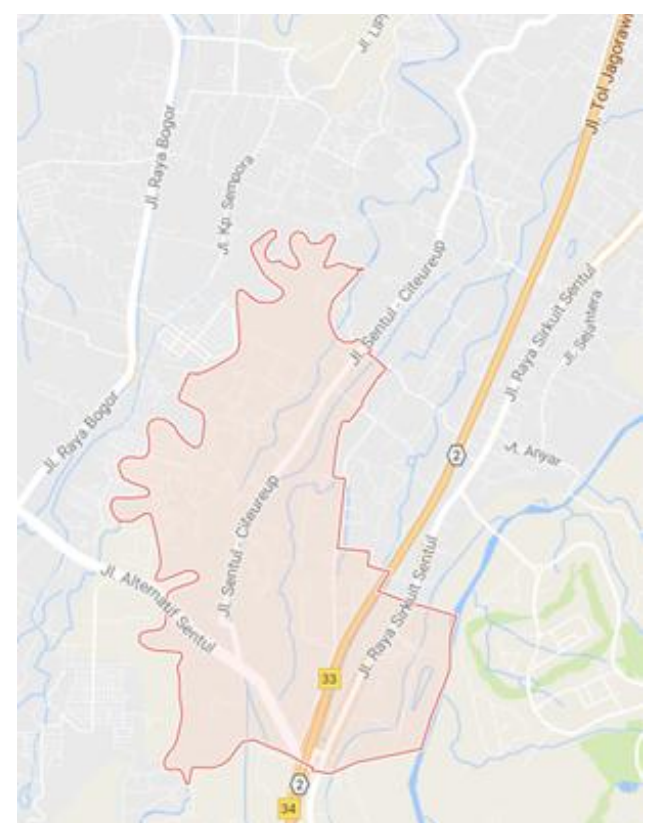

Gambar 1. Peta Sentul, Babakan Madang, Bogor, Jawa Barat

Di dalam kawasan industri ini masih terdapat lahan kosong untuk ditawarkan bagi pengembang industri baru seluas $48 \mathrm{Ha}$ dari total luas lahan sebesar $100 \mathrm{Ha}$ (BKPM, 2016). Penentuan calon lokasi pendirian pabrik ini didasarkan pada beberapa pertimbangan sebagai berikut: a. Kedekatan dengan letak sumber bahan baku.

Bahan baku yang digunakan untuk memproduksi karet bantalan untuk perletakan jembatan dan jalan layang terdiri atas karet baik alam maupun sintetik, dan bahan kimia karet. Karet alam mentah golongan RSS 1 dapat dipasok dari pabrik pengolahan karet 
mentah milik negara maupun swasta yang beroperasi di sekitar wilayah Jawa Barat dan berdekatan dengan Sentul misalnya PT. Perkebunan Nusantara VIII (Kebun Cikumpay di Purwakarta atau Kebun Jalupang di Subang), PT. Condong Garut (Garut), PT. Bajabang dan PT. Mampang Nugraha Prima (Cianjur). Sedangkan kebutuhan karet sintetik CR dan sebagian besar bahan kimia karet harus dipenuhi secara impor melaluisupplier atau distributor besar yang beroperasi di DKI Jakarta.Bahan kimia karet yang dapat diperoleh dari supplier lokal di sekitar Bogor adalah sulfur.

b. Kedekatan dengan lokasi pasar atau konsumen

Konsumen utama karet bantalan untuk perletakan jembatan dan jalan layang adalah industri infrastruktur dan konstruksi milik pemerintah (BUMN) maupun swasta yang umumnya memiliki kantor pusat di DKI Jakarta meskipun lokasi proyek pembangunannya dapat tersebar di seluruh Indonesia. Pengadaan karet bantalan untuk memenuhi kebutuhan proyek pembangunan tersebut sering kali harus melewati persetujuan kantor pusat. Calon konsumen terdekat adalah kontraktor pembangunan jalan layang di DKI Jakarta yang akan membangun jalan layang sepanjang $27.841 \mathrm{~m}$ sehingga akan menyerap sekitar 22.273 buah karet bantalan untuk perletakan jalan layang.

c. Akses transportasi dan pengangkutan

Posisi Kawasan Industri Sentul dinilai cukup strategis karena terletak dekat dengan pusat pemerintahan dan perdagangan, didukung dengan sarana prasarana transportasi yang cukup memadai sehingga mempermudah mobilisasi pengangkutan barang dari dan ke lokasi pabrik. Kawasan industri ini berjarak sekitar $45 \mathrm{Km}$ dari Ibukota Negara, $60 \mathrm{Km}$ dari Bandar Udara Internasional Soekarno-Hatta, $38 \mathrm{Km}$ dari Bandar Udara Halim Perdana
Kusuma dan $50 \mathrm{Km}$ ke Pelabuhan Tanjung Priok. Transportasi dapat diakses melalui jalur darat, baik dengan kendaraan kecil maupun berat karena tersedianya akses jalan yang beraspal hotmix dan lebar $14 \mathrm{~m}$ serta langsung terhubung dengan jalan Tol Jagorawi (berjarak sekitar $100 \mathrm{~m}$ dari pintu tol).

d. Ketersediaan sumber energi dan utilitas Pasokan air untuk pabrik yang akan didirikan di Kawasan Industri Sentul dapat diperoleh dari air tanah dengan kualitas air yang cukup baik. Sedangkan untuk kebutuhan listrik akan disuplai oleh PT. PLN dengan kapasitas total mencapai 18 MW. Untuk memenuhi kebutuhan bahan bakar seperti solar untuk menggerakkan mesin produksi dapat diperoleh dari PT. Pertamina Depo Plumpang Jakarta. Selanjutnya untuk kebutuhan gas akan dipasok oleh PT. PGN.

e. Ketersediaan sarana infrastruktur pendukung

Kawasan Industri Sentul didukung oleh fasilitas hunian seperti perumahan, hotel, area komersial dan pertokoan, sarana kesehatan serta gedung perkantoran. Kawasan ini juga ditunjang denganperencanaan pembangunan stasiun Light Rail Transit (LRT).

f. Ketersediaan tenaga kerja

Secara umum kebutuhan pabrik terhadap ketersediaan tenaga kerja profesional maupun lapangan dengan berbagai kualifikasi tingkat pendidikan dapat dipenuhi terutama dari daerahdaerah disekitar lokasi pabrik, antara lain Kabupaten/Kotamadya Bogor, Kotamadya Depok, dan DKI Jakarta. Dengan kemampuan penyerapan tenaga kerja, maka akseptabilitas masyarakat terutama yang berada di sekitar lokasi pendirian pabrik terhadap kehadiran pabrik menjadi semakin besar.

g. Kebijakan dan peraturan pemerintah Pemilihan calon lokasi pendirian pabrik karet bantalan untuk perletakan jembatan dan jalan layang di Kawasan Industri 
Sentul Kabupaten Bogor dirasakan telah tepat karena sesuai dengan Pasal 36 Ayat (2) dan (3) Peraturan Pemerintah Nomor 142 Tahun 2015 yang menyatakan bahwa perusahaan industri yang akan menjalankan industri, wajib untuk berlokasi di Kawasan Industri. Dengan demikian risiko perubahan pemilihan lokasi pabrik dapat diminimalisasi.

\section{Penentuan Kapasitas Produksi}

Kapasitas produksi karet bantalan untuk perletakan jembatan dan jalan layang dirancang hanya untuk memenuhi sekitar $30 \%$ potensi pasar yang masih terbuka yaitu sebesar 17.082 buah karet bantalan per tahun. Hal ini dengan mengambil pertimbangan bahwa industri karet bantalan jembatan dan jalan layang yang akan didirikan merupakan pemain baru yang akan bersaing dengan industri karet bantalan eksisting yang telah mapan dan memiliki target pasar yang jelas. Untuk itu strategi yang digunakan untuk merebut pangsa pasar oleh industri baru ini dilakukan secara bertahap dengan memasang kapasitas produksi awal sebesar 30\% dari potensi pasar yang masih terbuka.

Jenis karet bantalan untuk perletakan jembatan dan jalan layang yang akan diproduksi menggunakan bahan baku baik dari karet alam maupun karet sintetik kloroprena (CR). Produk karet bantalandipilih tipe berlapis (laminasi) yang lebih laku di pasar, karena memiliki kemampuan dalam menahan beban dan deformasi yang lebih besar dibandingkan dengan tipe polos. Produk karet bantalan yang akan dibuat dibedakan berdasarkan dimensinyayang terdiri atas jenis $1(350 \times 300$ x $36 \mathrm{~mm})$, jenis $2(400 \times 350 \times 39 \mathrm{~mm})$, dan jenis $3(450 \times 400 \times 45 \mathrm{~mm})$, dengan komposisi produksi proporsional. Ukuran tersebut mengikuti ukuran standar yang ditetapkan oleh Kementerian PUPR.Dengan menetapkan hari kerja selama 330 hari per tahun maka dapat diketahui kapasitas produksi karet bantalan per tahun dan per hari seperti dirinci dalam Tabel 3 berikut.

Tabel 3. Kapasitas produksi karet bantalan jembatan dan jalan layang

\begin{tabular}{|c|c|c|c|c|c|}
\hline \multirow{3}{*}{ Jenis karet bantalan } & \multirow{3}{*}{$\begin{array}{l}\text { Komposisi } \\
\text { produksi } \\
(\%)\end{array}$} & \multicolumn{4}{|c|}{ Kapasitas produksi (buah) } \\
\hline & & \multicolumn{2}{|c|}{ Karet alam $(75 \%)$} & \multicolumn{2}{|c|}{ Karet sintetik (25\%) } \\
\hline & & per tahun & per hari & per tahun & per hari \\
\hline Jenis $1: 350 \times 300 \times 36$ & 30 & 3.843 & 12 & 1.281 & 4 \\
\hline Jenis $2: 400 \times 350 \times 39$ & 35 & 4.484 & 14 & 1.495 & 5 \\
\hline Jenis $3: 450 \times 400 \times 45$ & 35 & 4.484 & 14 & 1.495 & 5 \\
\hline Total & 100 & 12.811 & 39 & 4.270 & 13 \\
\hline
\end{tabular}




\section{Teknologi Proses Produksi}

Proses produksi pembuatan karet bantalan untuk perletakan jembatan dan jalan layang tipe berlapis atau laminasi pada berbagai ukuran, baik dari karet alam maupun karet sintetik CR mencakup beberapa tahapan proses yaitu :

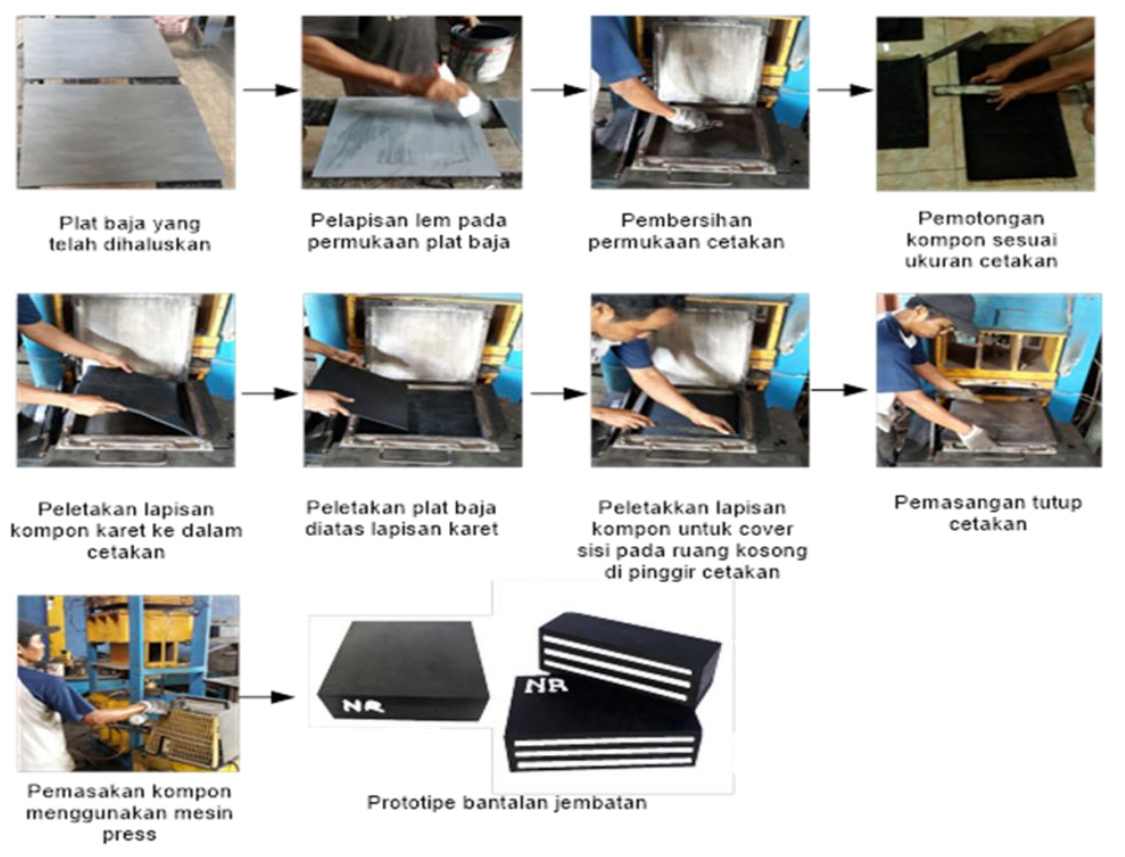

Gambar 2. Proses manufaktur karet bantalan jembatan dan jalan layang

1. Pembuatan kompon karet

Pembuatan kompon karet diawali dengan menetapkan formula kompon karet yang akan digunakan dalam proses produksi. Formula tersebut harus dapat memenuhi standar mutu karet untuk bantalan yang sesuai dengan SNI 3967:2013. Kompon karet dibuat dengan cara memastikasi karet hingga lunak dalam mesin giling terbuka (open mill). Selanjutnya ke dalam karet yang telah lunak ditambahkan bahan kimia karet pada dosis tertentu. Campuran karet dan bahan kimia digiling hingga membentuk kompon yang homogen. Pada akhir proses penggilingan, kompon karet dibentuk dalam wujud lembaran (rubber compound sheet). Lembaran kompon karet dipotong pada ukuran yang sesuai dengan dimensi karet bantalan yang akan diproduksi menggunakan alat horizontal bias cutter.
2. Persiapan pelat baja untuk karet bantalan Permukaan pelat baja yang akan digunakan sebagai struktur penguat karet bantalan untuk perletakan jembatan dan jalan layang diperhalus dengan teknik sand blasting. Pelat baja yang digunakan harus memiliki permukaan yang halus dan bersih dari minyak atau pelumas supaya lem yang akan diaplikasikan di permukaan dapat menempel dengan baik dan dapat memberikan rekatan yang kuat antara karet dengan pelat baja. Seperti pada kompon karet, pelat baja dipotong pada ukuran tertentu sesuai dengan dimensi produk karet bantalan yang akan diproduksi menggunakan alat saw metal cutting. Sudut-sudut pelat baja tidak boleh tajam dan kasar.

3. Pencetakan dan vulkanisasi kompon karet bantalan

Masing-masing potongan lembaran kompon karet dan pelat baja disusun berselang-seling di dalam cetakan karet 
untuk perletakan jembatan dan jalan layang. Kompon karet bantalan dan pasangan pelat baja yang telah tersusun dalam cetakan selanjutnya divulkanisasi pada suhu dan tekanan tinggi di dalam mesin tekan (compression moulding) sehingga terbentuk vulkanisat atau produk barang jadi karet bantalan untuk perletakan jembatan dan jalan layang.

\section{Kebutuhan Bahan dan Permesinan}

Kebutuhan bahan dan permesinan yang diperlukan untuk memproduksi karet bantalan untuk perletakan jembatan dan jalan layang disajikan dalam Tabel 4 dan 5 . Bahan kimia karet yang digunakan terdiri atas karet alam tipe RSS 1, karet sintetik CR, bahan antioksidasi dan antiozon, bahan bantu olah, bahan pengisi (reinforced filler), bahan pengaktif, bahan pencepat, dan bahan pemvulkanisasi.

Tabel 4. Kebutuhan bahan dalam produksi karet bantalan jembatan dan jalan layang

\begin{tabular}{clcccc}
\hline \multirow{2}{*}{ No } & \multicolumn{1}{c}{ Bahan } & \multicolumn{2}{c}{ Tipe karet bantalan } & \multicolumn{2}{c}{ Sumber perolehan } \\
& & NR & CR & Lokal & Impor \\
\hline 1 & Karet alam RSS1 & $\mathrm{X}$ & - & - & - \\
2 & Karet Neoprena (CR) & - & $\mathrm{X}$ & $\mathrm{X}$ & $\mathrm{X}$ \\
3 & Seng oksida - ZnO & $\mathrm{X}$ & $\mathrm{X}$ & - & $\mathrm{X}$ \\
4 & Magnesium oksida-MgO & - & $\mathrm{X}$ & - & $\mathrm{X}$ \\
5 & Asam Stearat & $\mathrm{X}$ & $\mathrm{X}$ & - & $\mathrm{X}$ \\
6 & Antiozonant & $\mathrm{X}$ & $\mathrm{X}$ & - & $\mathrm{X}$ \\
7 & Antioksidan 6PPD & $\mathrm{X}$ & $\mathrm{X}$ & - & $\mathrm{X}$ \\
8 & Antioksidan TMQ & $\mathrm{X}$ & $\mathrm{X}$ & - & $\mathrm{X}$ \\
9 & Antioksidan Polymeric & $\mathrm{X}$ & - & - & $\mathrm{X}$ \\
10 & Arang hitam CB N220 & $\mathrm{X}$ & $\mathrm{X}$ & - & $\mathrm{X}$ \\
11 & White oil & $\mathrm{X}$ & - & - & $\mathrm{X}$ \\
12 & Pelunak - Minarex & - & $\mathrm{X}$ & $\mathrm{X}$ & $\mathrm{X}$ \\
13 & Accelerator & - & $\mathrm{X}$ & - & $\mathrm{X}$ \\
14 & Bahan pencepat - CBS & $\mathrm{X}$ & - & - & - \\
15 & Bahan pencepat TMTD & $\mathrm{X}$ & $\mathrm{X}$ & - & $\mathrm{X}$ \\
16 & Belerang & $\mathrm{X}$ & - & & \\
\hline
\end{tabular}

Tabel 5.Mesin dalam produksi karet bantalan jembatan dan jalan layang

\begin{tabular}{cll}
\hline No & \multicolumn{1}{c}{ Nama alat - mesin } & \multicolumn{1}{c}{ Fungsi } \\
\hline 1 & Open Mill / Banbury Mixer & Pembuatan kompon baik dari karet NR maupun CR \\
2 & Batch-off Cooling Machine & Mendinginkan kompon karet sebelum diproses lanjut \\
3 & Horizontal Bias Cutter & Memotong lembaran kompon sesuai ukuran cetakan \\
4 & Sand Blasting Equipment & Memperhalus permukaan pelat logam \\
5 & Saw Metal Cutting & Memotong pelat logam sesuai ukuran cetakan \\
6 & Compression Moulding & Memvulkanisasi kompon karet bantalan NR dan CR \\
7 & Timbangan & Menentukan berat karet dan bahan kimia karet \\
8 & Cetakan / Mold & Membentuk karet bantalan sesuai tipe dimensinya \\
9 & Lori & Memindahkan bahan atau barang \\
10 & Forklift & Mengangkat bahan atau barang \\
11 & Bale Cutter & Memotong karet alam (NR) \\
12 & Bak Plastik & Wadah bahan kimia karet yang telah ditimbang \\
13 & Generator Set & Sumber pembangkit listrik cadangan
\end{tabular}


14 Instalasi Air

15 Instalasi Listrik

16 Instalasi Udara Tekan

17 Tangki Bahan Bakar
Menyalurkan kebutuhan air pendingin untuk Open Mill

Menyalurkan listrik untuk peralatan dan mesin produksi

Menunjang kinerja mesin Hydraulic Press Machine

Tempat penyimpanan bahan bakar untuk Genset

\section{Analisis Kelayakan Finansial}

Analisis kelayakan finansial pendirian industri karet bantalan untuk perletakan jembatan dan jalan layang disusun berdasarkan asumsi sebagai berikut :

1. Analisis finansial dilakukan dalam jangka waktu 10 tahun dengan tahun ke-0 digunakan sebagai tahap persiapan dan pembangunan fisik pabrik.

2. Kapasitas pabrik karet bantalan dirancang sebesar 17.000 unit per tahun. Pada tahun ke-1 pabrik beroperasi pada kapasitas $60 \%$, tahun ke-2 sebesar $80 \%$, tahun ke-3 dan seterusnya sebesar $100 \%$.

3. Komposisi produk karet bantalan : $30 \%$ Jenis 1, 35\% Jenis 2 dan 35\% Jenis 3, baik untuk karet bantalan dari karet alam maupun karet CR.

4. Harga jual produk karet bantalan jenis 1 sebesar IDR 1.560.000, jenis 2 sebesar 1.820.000, dan jenis 3 sebesar IDR 2.080.000

5. Lokasi pabrik dipilih di Kawasan Industri Sentul, Kecamatan Babakan Madang, Kabupaten Bogor, Provinsi Jawa Barat.

6. Harga bahan baku karet :karet alam RSS1 USD 1,5 per kg, karet CR USD 3 per kg.

7. Nilai tukar IDR terhadap USD sebesar USD 1 = IDR 13.500

8. Dalam satu tahun ditetapkan sebanyak 330 hari kerja dan setiap hari digunakan 3 shift masing-masing 8 jam kerja.

9. Jumlah karyawan tetap sebanyak 24 orang, dan operator pabrik (outsourcing) sebanyak 30 orang

10. Biaya penyusutan dihitung dengan metode garis lurus yang disesuaikan dengan umur ekonomis masing-masing modal tetap. Umur ekonomis bangunan adalah 20 tahun, mesin dan peralatan 10 tahun, dan kendaraan 5 tahun.

11. Biaya pemeliharaan dihitung sebesar $1 \%$ dari nilai sisa asset untuk bangunan, $2 \%$ mesin dan alat, 1,5\% instalasi pendukung, $2 \%$ alat tulis kantor, dan 3\% kendaraan.

12. Biaya asuransi ditetapkan $0,5 \%$ dari nilai setiap aset pada tahun berjalan.

13. Debt equity ratio sebesar $65: 35$ yaitu $65 \%$ modal pinjaman dan $35 \%$ modal sendiri.

14. Reject produk karet bantalan pada tahun ke-1 : $6 \%$, ke-2 : $4 \%$, dan ke-3 : $2 \%$. Selanjutnya tingkat reject sangat rendah sehingga dapat diabaikan.

15. Tingkat suku bunga pinjaman sebesar $10,5 \%$ dan faktor diskonto sebesar $14 \%$.

16. Pajak penghasilan dihitung berdasarkan UU Nomor 36 Tahun 2008.

Komponen-komponen dalam perhitungan kelayakan finansial yang meliputi biaya investasi dan modal kerja, sumber pendanaan, dan biaya operasional disajikan dalam Lampiran pada bagian akhir kajian ini.Laporan rugi laba merupakan ringkasan penerimaan dan pembiayaan perusahaan setiap periode akuntansi dan memberikan suatu gambaran kegiatan industri karet bantalan jembatan dan jalan layang dari waktu ke waktu. Akumulasi pendapatan selama umur ekonomis (10 tahun) adalah sebesar IDR 366 Milyar sedangkan total biaya operasi sebesar IDR 168 Milyar. Di dalam laporan rugi laba dihasilkan nilai akumulasi laba bersih yang merupakan pendapatan dikurangi biaya operasi, bunga modal pinjaman dan pajak penghasilan. Berdasarkan perhitungan, pada akhir periode kajian akumulasi laba bersih yang dihasilkan adalah IDR 137 Milyar. 
Proyeksi arus kas terdiri atas komponen kas masuk dan kas keluar. Kas masuk terdiri atas investasi dan modal kerja, bunga masa konstruksi, laba bersih dan penyusutan. Sementara kas keluar terdiri atas pembiayaan investasi dan modal kerja serta pembayaran pokok pinjaman. Arus kas bersih merupakan pengurangan dari kas masuk dan kas keluar setiap periode akuntansi. Akumulasi kas bersih merupakan akumulasi arus kas bersih tiap tahun. Proyeksi arus kas operasional pabrik karet bantalan jembatan dan jalan layang pada tahun pertama menunjukkan nilai yang positif yaitu sebesar IDR 4,1 Milyar. Pada akhir periode analisis (10 tahun), total kas akhir sebesar IDR 630 Milyar.
Selanjutnya hasil analisis kelayakan finansial investasi pembangunan pabrik karet bantalan untuk perletakan jembatan dan jalan layang menunjukkan bahwa industri ini layak beroperasi mengacu pada nilai NPV (Net Present Value), IRR (Internal Rate Of Return), B/C (Benefit Cost Ratio) dan PBP (Pay Back Period) seperti disajikan dalam Tabel 6. Hasil studi analisis kelayakan finansial industri karet bantalan jembatan dan jalan layang yang dioperasikan pada kapasitas produksi sebesar 17.000 buah per hari memberikan nilai NPV sebesar IDR 14,22 Milyar (bernilai positif atau lebih besar dari nol), IRR sebesar 20,10\% (lebih besar dari faktor diskonto $14 \%$ ), $\mathrm{B} / \mathrm{C}$ ratio sebesar 1,22 (lebih besar dari 1) dan PBP selama 4,78 tahun.

Tabel 6.Kelayakan finansial investasi pabrik karet bantalan

\begin{tabular}{lr}
\hline \multicolumn{1}{c}{ Indikator kelayakan } & Nilai \\
\hline Net Present Value - NPV (IDR) & $14.218 .844 .662,-$ \\
Internal Rate of Return - IRR (\%) & 20,10 \\
Net Benefit Cost Ratio - B/C ratio & 1,22 \\
Payback Period - PBP (Tahun) & 4,78 \\
\hline
\end{tabular}

\section{Analisis Sensitivitas}

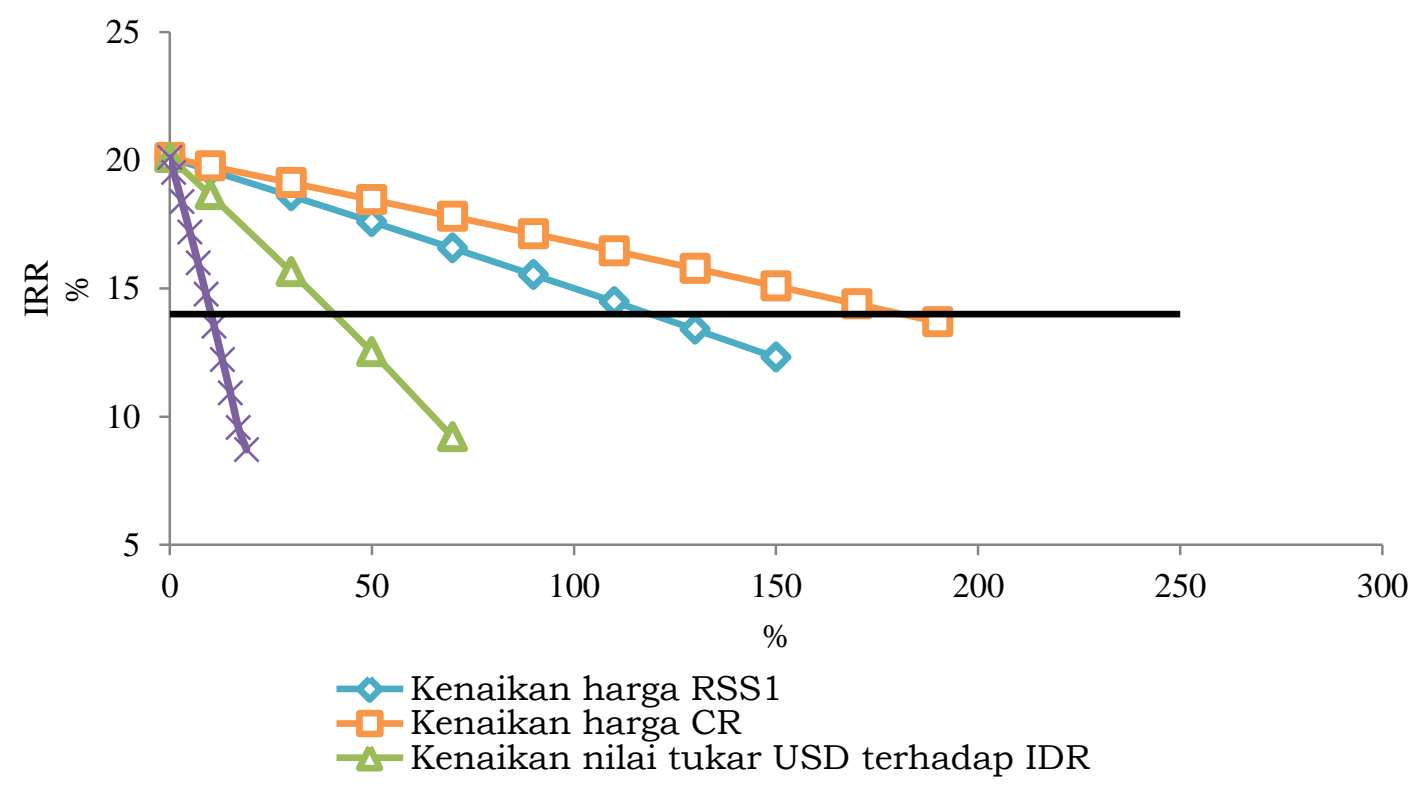

Gambar 3. Sensitivitas kelayakan investasi pada industri karet bantalan 
Analisis sensitivitas diperlukan untuk mengetahui tingkat kelayakan industri karet bantalan untuk perletakan jembatan dan jalan layang apabila terdapat perubahan terhadap variabel produksi. Analisis sensitivitas pada kajian ini mengambil beberapa sekrenario sebagai berikut:

1. Kenaikan harga bahan baku karet sit asap (RSS1).

2. Kenaikan harga bahan baku karet sintetik neoprena (CR).

3. Kenaikan nilai tukar USD terhadap IDR.

4. Penurunan harga jual produk karet bantalan.

Hasil perhitungan analisis sensitivitas pada berbagai sekrenario terhadap nilai IRR disajikan dalam Gambar 3. Dari Gambar 3 diketahui bahwa tingkat kelayakan investasi pembangunan industri karet bantalan untuk perletakan jembatan dan jalan layang sangat sensitif terutama terhadap skenario penurunan harga jual produk dan kenaikan nilai tukar USD terhadap IDR (melemahnya nilai IDR). Sedangkan skenario kenaikan harga bahan baku karet alam RSS 1 dan karet sintetik CR tidak berpengaruh signifikan terhadap kelayakan finansial pendirian pabrik karet bantalan untuk perletakan jembatan dan jalan layang. Faktor nilai tukar USD terhadap IDR sangat berpengaruh terhadap kelayakan finansial karena sebagian besar bahan kimia karet yang diperlukan dalam manufaktur karet bantalan jembatan dan jalan layang seperti bahan antioksidasi, bahan antiozon, bahan pencepat, bahan pengaktif, bahan bantu olah dan bahan pengisi harus dipenuhi secara impor. Selanjutnya harga jual produk karet bantalan jembatan dan jalan layang akan menentukan jumlah pendapatan dan laba yang akan digunakan untuk membiayai produksi dan operasional lainnya.

\section{Kesimpulan}

Industri karet bantalan untuk perletakan jembatan dan jalan layang merupakan industri hilir karet yang patut untuk segera dikembangkan sebagai upaya untuk mendukung pemerintah dalam meningkatkan penyerapan domestik karet alam. Selain itu industri ini memiliki prospek pasar yang cukup menjanjikan akibat dampak dari akan diberlakukannya kebijakan Pemerintah yang mewajibkan penggunaan karet alam sebagai elemen pendukung dalam pembangunan infrastruktur nasional. Pada kapasitas produksi sebesar 17.000 buah karet bantalan per tahun dengan komposisi $75 \%$ karet bantalan dari karet alam dan 25\% dari karet sintetik tipe kloroprena (CR), industri yang direncanakan akan didirikan di Kawasan Industri Sentul, Kecamatan Babakan Madang, Kabupaten Bogor, Provinsi Jawa Barat ini diketahui layak beroperasi karena memberikan NPV bernilai positif, IRR lebih besar dari faktor diskonto, B/C ratio lebih besar dari 1. Industri karet bantalan jembatan dan jalan layang ini sangat sensitif terhadap penurunan harga jual produk dan kenaikan nilai tukar USD terhadap IDR.

\section{Ucapan Terima Kasih}

Ucapan terima kasih dan penghargaan tinggi disampaikan kepada Kementerian Riset, Teknologi, dan Pendidikan Tinggi atas dukungan pendanaan melalui program penelitian dan pengembangan Insentif Sistem Inovasi Nasional (INSINAS) Tahun Anggaran 2016 (Nomor Kontrak 293/SP2H/LT/DRPM/III/2016) dengan kode proyek penelitian Insinas RT-2016-0019 sehingga studi tekno-ekonomi ini dapat terselesaikan dengan baik.

\section{Daftar Pustaka}

Alam, M. S., Bhuiyan, M. A. R., and Billah, A. H. M. M. (2012). Seismic fragility assessment of SMA-bar restrained multispan continuous highway bridge isolated by different laminated rubber bearings in medium to strong seismic risk zones. Bulletin Earthquake Engineering, 10, 18851909. doi: 10.1007/s10518-012-9381-8. 
Alam, M. S., and Bhuiyan, A. R. (2012). Use of shape memory alloys with laminated rubber bearings in seismic isolation of multi-span continuous moderate to strong seismic zones. Proceedings of the $15^{\text {th }}$ World Conference on Earthquake Engineering, Lisbon, September 2012.

Asl, M. J., Rahman, M. M., and Karbakhsh, A. (2014). Numerical analysis of seismic elastomeric isolation bearing in the base isolated buildings. Open Journal of Earthquake Research, 3, 1-4. doi: 10.4236/ojer.2014.31001.

Aviram, A., Schellenberg, A., and Stojadinovic, B. (2012). Seismic design and performance of two isolation system used for reinforced concrete bridge construction. Proceedings of the $15^{\text {th }}$ World Conference on Earthquake Engineering, Lisbon, September 2012.

Bhuiyan, M. A. R., and Alam, M. S. (2012). Seismic vulnerability assessment of a multi-span continuous highway bridge fitted with shape memory alloy bars and laminated rubber bearings. Earthquake Spectra, 28(4), 1379-1404.

Choun, Y. S., Park, J. H., and Choi, I. K. (2014). Effects of mechanical property variability in lead rubber bearings on the response of seismic isolation system for different ground motions. Nuclear Engineering and Technology, 46(5), 605-618. doi: 10.5516/NET.09.2014.718.

Filipov, E. T., Fahnestock, L. A., Steelman, J. S., Hajjar, J. F., LaFave, J. M., and Foutch, D. A. (2013). Evaluation of quasiisolated seismic bridge behavior using nonlinear bearing models.Engineering Structure, 49, 168-181. doi: 10.1016/j.engstruct.2012.10.011.

$\mathrm{Gu}, \mathrm{H}$. S., and Itoh, Y. (2012). Aging inside natural rubber bearings and prediction method.Journal of Beijing University of Technology, 38(2), 186-193.
Haque, M. N., Bhuiyan, A. R., and Alam, M. J. (2010). Seismic response analysis of base isolated highway bridge: Effectiveness of using laminated rubber bearings. Proceedings of IABSE-JSCE Joint Conference on Advances in Bridge EngineeringII, Dhaka, Augustus 2010.

Haque, Md. N., Zisan, Md. B., and Bhuiyan, A. R. (2013). Seismic response analysis of base isolated building: Effect of lead rubber bearing characteristics. Malaysian Journal of Civil Engineering, 25(2), 154-167.

Iancu, V., Vasile, O., and Gillich, G. R. (2012). Modelling and characterization of hybrid rubber-based earthquake isolation system. Materiale Plastice, 49(4), 237-241.

Itoh, Y., and Gu, H. S. (2009). Prediction of aging characteristics in natural rubber bearings used in bridges. Journal of Bridge Engineering, 14(2), 122-128. doi: 10.1061/(ASCE)10840702(2009)14:2(122).

Kitahara, T., Kajita, Y., and Kitane, Y. (2012).Investigation on the damage cause of the bridge rubber bearing in the 2011 of the Pacific coast of Tohoku Earthquake.Proceedings of the $15^{\text {th }}$ World Conference on Earthquake Engineering, Lisbon, September2012.

Liu, H., Wang, X., Sun, F., and Ou, J. (2008). Shaketable test of seismic isolation structure based on SMA wire-laminated rubber combined bearings. Proceedings of the $14^{\text {th }}$ World Conference on Earthquake Engineering, Beijing, October 2008.

Manos G. C., Mitoulis, S., Kourtidis, V., Sextos, A., and Tegos, I. (2007).Study of the behavior of steel laminated rubber bearings under prescribed loads. Proceedings of $10^{\text {th }}$ World Conference on Seismic Isolation, Energy Dissipation and Active Vibrations Control of Structure, Istambul, May2007. 
Ohkura, S., Kitane, Y., and Itoh, Y. (2011). Solar radiation effect on internal temperature of rubber bridge bearing. Proceedings of the Twenty-Fourth KKCNN Symposium on Civil Engineering, Hyogo, December 2011.

erimental Structural Engineering, Ispra, June2011.

Ravari, A. K., Othman, I., Ibrahim, Z., and Hashamdar, H. (2011).Variations of horizontal stiffness of laminated rubber bearings using new boundary conditions. Scientific Research and Essays, 6(14), 30653071.

Ravari, A. K., Othman, I., Ibrahim, Z., and Ab-Malek, K. (2012). P- $\Delta$ and end rotation effects on the influence of mechanical properties elastomeric isolation bearings. Journal of Structural Engineering, $138, \quad 6 . \quad$ doi: 10.1061/(ASCE)ST.1943-541X.0000503

Razzaq, M. K., Bhuiyan, A. R., Okui, Y., Mitamura, H., and Imai, T. (2010). Effect of rubber bearing's modeling on seismic response of base isolated highway bridge. Joint Conference Proceedings. $7^{\text {th }}$ International Conference on Urban Earthquake Engineering\& $5^{\text {th }}$ International Conference on Earthquake Engineering, Tokyo, March 2010.

Sanchez, J., Masroor, A., Mosqueda, G., and Ryan, K. (2013).Static and dynamic
Ohkura, S., Paramashanti., Kitane, Y., and Itoh, Y. (2011). Long-term temperature measurement of rubber bridge bearing exposed to solar radiation for aging estimation. Proceedings of $4^{\text {th }}$ International Conference on Advances in Exp stability of elastomeric bearing for seismic protection of structures.Journal of Structural Engineering,139(1), 1149-1159.doi: 10.1061/(ASCE)ST.1943-541X.0000660.

Steelman, J. S, Fahnestock, L. A., Filipov, E. T., LaFave, J. M, Hajjar, J. F., and Foutch, D. A. (2013). Shear and friction response of nonseismic laminated elastomer bearings subject to seismic demands.Journal of Bridge Engineering, 18(7), 612-623. doi: 10.1061/(ASCE)BE.1943-5592.0000406.

Warn, G. P., and Ryan, K. L. (2012). A review of seismic isolation for buildings: Historical development and research needs. Buildings, 2, 300-325. doi: 10.3390/buildings2030300.

Weisman, J., and Warn, G. P. (2012). Stability of elastomeric and lead rubber seismic isolation bearings.Journal of Structural Engineering, 138(2), 215-223. doi: 10.1061/(ASCE)ST.1943-541X.0000459.

Yachya, H. (1988). Studi kelayakan industri kecil bantalan jembatan.Menara Perkebunan, 52(2), 53-56. 
Lampiran1. Perincian biaya investasi pembangunan pabrik karet bantalan jembatan dan jalan layang

\begin{tabular}{|c|c|}
\hline Komponen Biaya & Jumlah (IDR) \\
\hline Lahan & 14.000 .000 .000 \\
\hline Bangunan & 7.050 .000 .000 \\
\hline Mesin dan peralatan & 17.844 .322 .790 \\
\hline Instalasi penunjang & 3.562 .000 .000 \\
\hline Alat Kantor dan Transportasi & 1.500 .000 .000 \\
\hline Biaya Pra Operasi & 115.723 .192 \\
\hline Biaya Investasi & 44.072 .045 .982 \\
\hline Bunga masa konstruksi (IDC) & 3.228 .244 .849 \\
\hline Biaya Investasi + IDC & 47.300 .290 .831 \\
\hline Provisi bank dan commitment fee & 307.451 .890 \\
\hline Total Biaya Investasi & 47.607 .742 .722 \\
\hline
\end{tabular}

Perincian modal kerja pabrik karet bantalan jembatan dan jalan layang

\section{Pembelian Bahan Baku} Komponen Biaya

Biaya Operasional

Modal Kerja

Provisi bank dan commitment fee

$\begin{array}{r}\text { Jumlah (IDR) } \\ 1.268 .185 .498 \\ 1.646 .732 .647 \\ 2.914 .918 .145 \\ 18.946 .968 \\ \hline 2.933 .865 .113 \\ \hline\end{array}$

Sumber pendanaan untuk biaya investasi dan modal kerja

\begin{tabular}{lrrr}
\hline \multirow{2}{*}{ Komponen Biaya } & \multicolumn{2}{c}{ Sumber Pembiayaan (IDR) } & \multirow{2}{*}{ Jumlah (IDR) } \\
\cline { 2 - 3 } & \multicolumn{1}{|c}{ Bank, 65\% } & Dana Sendiri, $35 \%$ & \\
\hline Biaya investasi & 30.945 .032 .769 & 16.662 .709 .953 & 47.607 .742 .722 \\
Modal kerja & 1.907 .012 .324 & 1.026 .852 .790 & 2.933 .865 .113 \\
\hline \multicolumn{1}{c}{ Total } & 32.852 .045 .093 & 17.689 .562 .742 & 50.541 .607 .835 \\
\hline
\end{tabular}

Perincian biaya operasional pabrik karet bantalan jembatan dan jalan layang

\begin{tabular}{lrr}
\multicolumn{2}{c}{ Komponen Biaya } & \multicolumn{1}{c}{ Jumlah (IDR) } \\
\hline & \multicolumn{1}{c}{ Biaya Tetap } & \\
Gaji Karyawan & & 20.760 .000 .000 \\
Penyusutan & & 25.093 .190 .511 \\
Pemeliharaan dan Perbaikan & 5.253 .164 .558 \\
Biaya Asuransi & & 901.736 .377 \\
Administrasi & & 2.869 .762 .368 \\
Total Biaya Tetap & Biaya Variabel & 54.877 .853 .814 \\
& & \\
Bahan Baku & & 89.009 .712 .814 \\
Bahan Pembantu & & 295.626 .240 \\
Tenaga Kerja & & 11.370 .240 .000 \\
Biaya Utilitas & & 3.222 .146 .079 \\
Promosi dan pemasaran & 9.475 .200 .000 \\
Total Biaya Variabel & Jumlah Biaya & 113.372 .925 .133 \\
\hline \multicolumn{2}{c}{$\quad 168.250 .778 .947$} \\
\hline
\end{tabular}

